学術論文

\title{
非接触給電機構および誘導機構を有する消化管用体内ロボットの検討 Examination of Wireless Power Transfer and Induction Mechanism in the Robot inside the Body for Digestive Tract
}

\author{
中山 徳人*(学生員), 卜 穎剛" (正員), 水野 勉* (正員)
}

Norito NAKAYAMA* (Stu. Mem.), Yinggang BU* (Mem.), Tsutomu MIZUNO* (Mem.)

\begin{abstract}
Capsule endoscopes in practical use are being driven by a battery. Also it relies on movement of the body peristalsis. It is expected to be able to freely move can reduce examination time also by the installation of the Induction mechanism. It is difficult to cover all only by the capacity of the battery in terms of adding various functions. It is expected to be equipped with a wireless power transfer technology as its solution. In this paper examined the mutual impact for mounting a Induction and the wireless power transfer mechanism simultaneously. Received power of wireless power transfer mechanism decreased. However $30 \mathrm{~mW}$ or more necessary to drive the capsule endoscope was obtained. Driving force of the Induction mechanism was improved.

Keywords: wireless power transfer, Induction, capsule endoscope, robot inside the body, digestive organs.
\end{abstract}

(2017 年 1 月 28 日受付,2017 年 4 月 21 日再受付)

\section{1 まえがき}

現在，医療現場において消化管の診断には消化管内 視鏡が広く用いられている。その例として経口内視鏡 や経鼻内視鏡などが挙げられる。経口内視鏡や経鼻内 視鏡などにより, 従来必要とされていた外科手術が不 要となるために, 患者に与える負担の少ない診察が可 能となった。

しかし，チューブ型の内視鏡であるため、苦痛や不 快感が強く、鎮静剤が必要となる場合も多い。また, 小腸は口からも肛門からも遠く、4〜 $6 \mathrm{~m}$ と長いため, 通常の上部消化管・大腸内視鏡は挿入困難である。

それに対し近年，カプセルサイズの飲み込むことが 可能な内視鏡 “カプセル内視鏡” が新たに開発された [1]。現在では, カプセル内視鏡のもつ診察機能に加え て, 治療機能や誘導機能などの様々な機能をもたせた “体内ロボット”が期待されている[2]。現状のカプセ ル内視鏡において体内での移動が，蠕動運動に依存し ている問題点がある。移動の制御ができないことによ り, 病変部への到達に時間がかかる問題があることや カプセル内視鏡患者の 1〜2\%程度において狭窄部な どで滞留する課題が発生している[3]。さらには病変部 を見逃す可能性もあり，消化管内を自由自在に移動可

連絡先：水野 勉, 广380-0928 長野市若里 4-17-1 信州大学工学部電気電子工学科西棟 水野・ 卜研究室, e-mail: mizunot@shinshu-u.ac.jp *信州大学
能な機能が求められている。また，カプセルが体内の どこにあるか分からなくなる事例もあり, 正確な位置 を検出可能な機能を搭載することで，より精度の高い 診察を行うことが求められている[4]。そのためにカプ セル内視鏡の誘導に必要な駆動機構の検討が進められ ている。

これら三機能(治療機能・自走機能・位置検出機能) を同時に搭載するための駆動電力を内部のバッテリだ けで賄うのは難しく, ワイヤレスでの電力供給を可能 にする非接触給電の技術を応用することが有効である [2-5]。しかし, 高周波電磁界は熱作用や刺激作用を与 えるとして, 国際非電離放射線防護委員会(ICNIRP)等 によりガイドラインが制定されている[6,7]。非接触給 電においても高周波電磁界を生じさせるために, 同ガ イドラインを遵守することが必要となる。

そこで，筆者らは体内ロボットシステムとして誘導 機構と非接触給電機構を同時に搭載するために両機構 による相互の影響を検討した。その際の問題として非 接触給電機構において誘導用永久磁石を受電コイルの 近くに配置した場合に受電電力が低下寸る現象が生じ た。

本論文では, 非接触給電機構に用いる受電コイルの 近くに誘導用永久磁石を配置した場合や誘導磁界を印 加した場合の受電電力特性と誘導用永久磁石の近くに 受電コイルを配置したカプセルの推進力特性について 述べる。また，誘導用永久磁石を近くに配置した場合 の受電電力低下の解決策として共振周波数の変化が考 
えられるので伝送磁界の周波数を調整する検討を行っ た。また, 永久磁石の $\mathrm{Ni}$ 薄膜での渦電流損による受電 電力の減衰が考えられるため, $\mathrm{Ni}$ 薄膜の代わりに樹脂 被膜をもつ永久磁石を使用して受電電力の検討を行っ た。

本論文では，以下の事項について述べる。

(1) 受電コイルの受電電力特性

(2) カプセルの推進力特性

\section{2 体内口ボットのシステム構成}

Fig.1 に体内ロボット駆動システムを示した。発振器 より制御された電流を電力増幅器によって増幅して, 身体の周囲に配置した複数のコイルにより任意の磁界 を発生させて電力伝送やカプセル内の永久磁石との磁 力により誘導を行う。また, 磁界を発生させる際, ICNIRP のガイドラインを遵守する必要がある。カプ セルが腸内の狭窄部において滞留しないようにカプセ ル内の永久磁石のグレードや容量, 外部磁界を大きく する必要がある。

Fig. 2 にカプセルの構造を示した。カプセルはØ11 $\mathrm{mm}$, 長さ $26 \mathrm{~mm}$ であり, 内部には非接触給電用の受 電コイルと整流回路用の基板, および誘導用の永久磁 石を内蔵した。受電コイルの寸法は, $\varnothing 10 \mathrm{~mm}$ 長さ 5 $\mathrm{mm}$ であり, 永久磁石の寸法は $\varnothing 9 \mathrm{~mm}$ 長さ $2 \mathrm{~mm}$ で 2 個用いた。(以下、永久磁石の長さを $l_{\mathrm{PM}}$ とする。)本実 験では，整流回路分のギャップを基板で代用した。

Fig. 3 に受電コイルの構造を示した。受電コイルは フェライトコアを用いて, どのような角度から磁界が 印加されても受電できるように三軸にコイルをコイル $\mathrm{A}$, コイル $\mathrm{B}$, コイル $\mathrm{C}$ と巻いた。また, 各受電コイ ルの出力電力を、倍電圧回路を用いて昇圧し、平滑コ ンデンサにより整流した。また、共振用コンデンサ $C_{\mathrm{A}}$, $C_{\mathrm{B}}, C_{\mathrm{C}}$ は，それぞれ受電コイルのインダクタンスと電 力伝送周波数を直列共振の式より選定した後, 実際に 電力伝送を行い各コイルの受電電力が最大となる周波 数が同じになるように再度, コンデンサを選定した。 受電電力整流用コンデンサ $\mathrm{C}$ は $1 \mu \mathrm{F}$ とした。

Table.1 に受電コイルの仕様を示した。本実験では, 各コイルの受電電力が最大となった $f=674 \mathrm{kHz}$ におけ る受電コイルの仕様を示した。各コイルの巻数は, そ れぞれ $N_{\mathrm{A}}=95, N_{\mathrm{B}}=110, N_{\mathrm{C}}=119$ であり $Q$ 值はそれぞ れ $Q_{\mathrm{A}}=124, Q_{\mathrm{B}}=143, Q_{\mathrm{C}}=147$ であった。

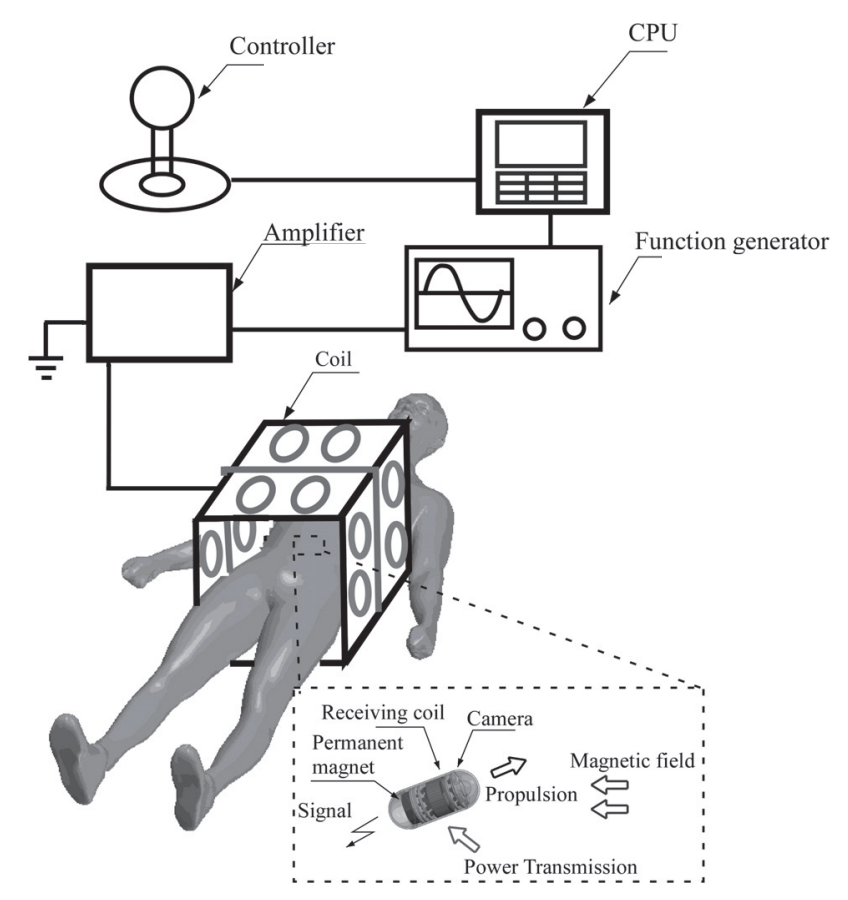

Fig. 1 Driver system of the robot inside the body.

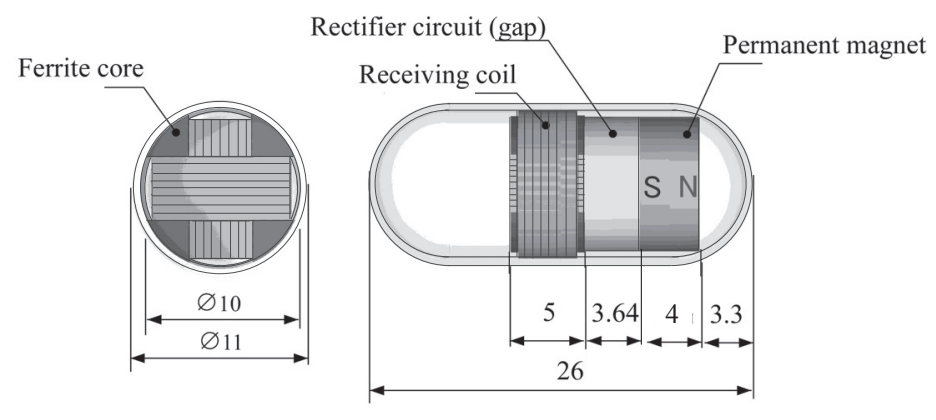

Fig. 2 Structure of capsule (unit : mm).

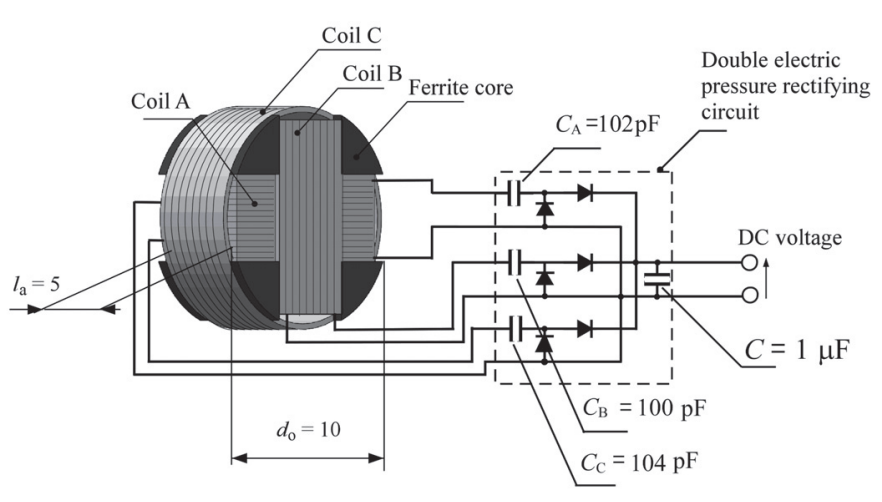

Fig. 3 Structure of receiving coil (unit : $\mathrm{mm}$ ). 
Fig.4 に永久磁石の構造を示した。寸法は $\varnothing 9 \mathrm{~mm} \times 2$ $\mathrm{mm}$ でグレードが $\mathrm{N} 52, \mathrm{Ni}$ 被膜なし樹脂コーティング した構造である。 Ni 薄膜の無い永久磁石を用いたのは, $\mathrm{Ni}$ 被膜に送電磁界が鎖交して生じる渦電流損を低減 させるためである。本実験では，カプセル空間の都合 上 2 個の永久磁石を用いて $l_{\mathrm{PM}}=4 \mathrm{~mm}$ とした。

Fig. 5 に巻線の構造を示した。 $\varnothing 90 \mu \mathrm{m}$ の銅線の外周 に $\mathrm{Ni}$ 薄膜と $\mathrm{Fe}$ 薄膜がめっきされている磁性めっき線 を用いた。また，磁性薄膜の外側には絶縁被膜が設け られており, 外径は $110 \mu \mathrm{m}$ である。

\section{3 受電電力特性}

Fig.6 に受電電力測定ブロック図を示した。NF 回路 設計ブロック社製発振器(WF 1974)から出力した信号 を NF 回路設計ブロック社製増幅器(NF HSA4014)で増 幅し, 一様磁界発生装置(SB-9)へ印加した。一様磁界 発生装置はコイルの体積 $20 \%$ 範囲において, 中心部 分の磁界から偏差 1\% 以内の磁界を発生する[8]。SB-9 に流れる電流を変化させて内部の磁界強度を ICNIRP のガイドライン $H=80 \mathrm{~A} / \mathrm{m}$ に調整し, 発生した磁界に より受電した電力を YOKOGAWA 製パワーアナライ ザ(WT 1800)で測定した。

Fig. 7 に回転に対する受電コイルの角度を示した。 一様磁界発生装置によって発生させた送電磁界が受電 コイルのコイルC に垂直に鎖交する角度を $\theta=90^{\circ} \varphi=$ $0 \circ$ とした。受電コイルの角度 $\varphi$ をパラメータとした角 度 $\theta$ に対する電力伝送を行った。また, 最低受電電力 を出力した受電コイルの角度において誘導磁界 $(10 \mathrm{mT})$ の角度 $\beta$ をパラメータとした角度 $\alpha$ に対する電 力伝送も行った。整流回路分のギャップの長さは, 基 板を用いて $3.64 \mathrm{~mm}$ とした。また，永久磁石は Fig. 4 に示したものを用いて $l_{\mathrm{PM}}=4 \mathrm{~mm}$ とした。
Table 1 Specification of the receiving coil $(f=674 \mathrm{kHz})$.

\begin{tabular}{l|c|c|c}
\hline & Coil A & Coil B & Coil C \\
\hline $\begin{array}{l}\text { Copper wire } \\
(\mu \mathrm{m})\end{array}$ & $\varnothing 90$ & $\varnothing 90$ & $\varnothing 90$ \\
\hline $\begin{array}{l}\text { Number of } \\
\text { turns }, N\end{array}$ & 95 & 110 & 119 \\
\hline $\begin{array}{l}\text { Inductance } \\
L(\mu \mathrm{H})\end{array}$ & 442 & 527 & 572 \\
\hline $\begin{array}{l}\text { Resistance } R(\Omega) \\
\text { Quality factor } \\
Q\end{array}$ & 13.0 & 15.1 & 19.5 \\
\hline
\end{tabular}

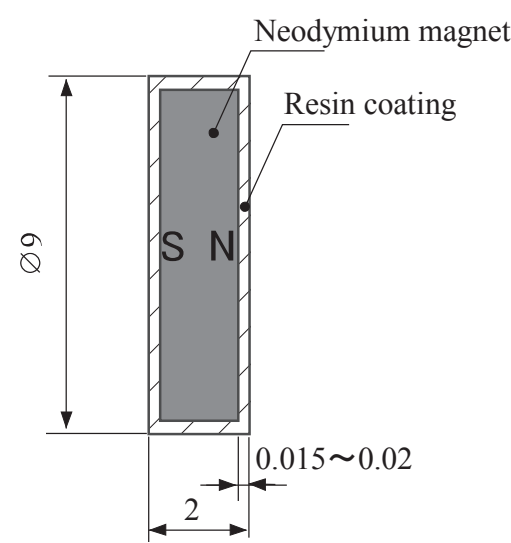

Fig. 4 Sectional view of permanent magnet (unit : $\mathrm{mm}$ ).

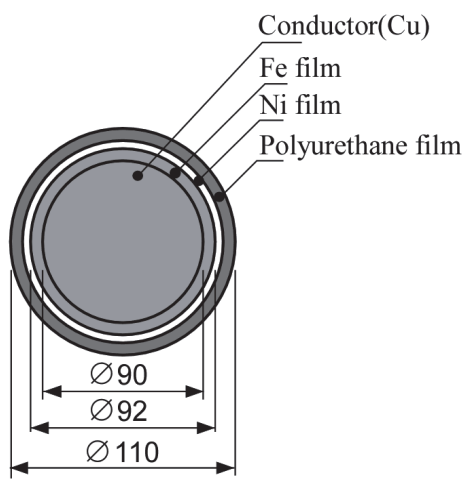

Fig. 5 Structure of winding wire for coil (unit : $\mu \mathrm{m})$.

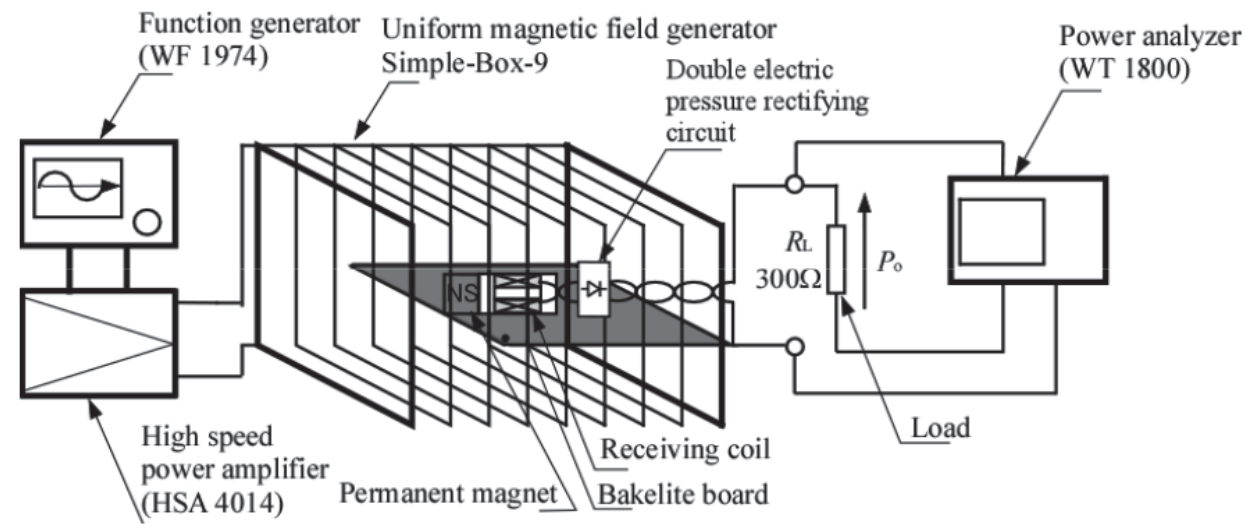

Fig. 6 Received power measurement block diagram. 


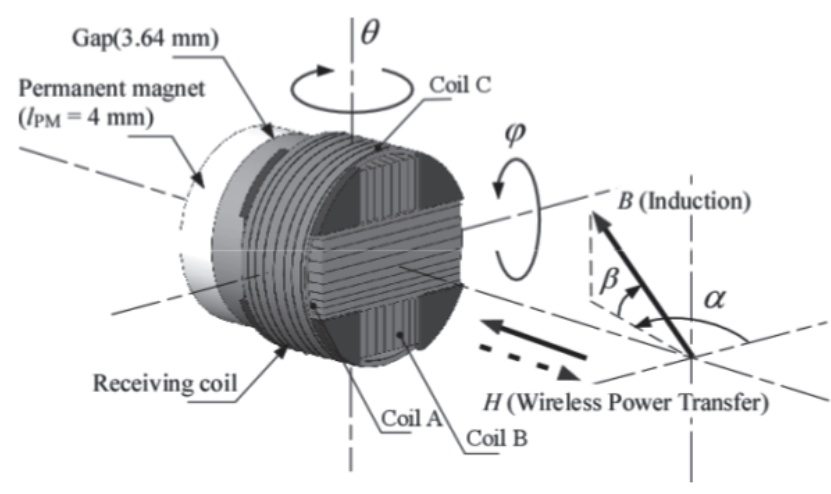

Fig. 7 Sectional view of Permanent magnet.

Fig. 8 に受電コイルのインピーダンス特性を示した。 (a)に受電コイルのインダクタンス-周波数特性を示し, (b)に受電コイルの抵抗-周波数特性を示し, (c)に $Q$ 值周波数特性を示した。周波数は, $Q$ 值や受電電力が最 大となる $700 \mathrm{kHz}$ 帯を使用した[9]。本実験では，実際 の伝送実験で受電電力が最も大きい $f=674 \mathrm{kHz}$ とした。 $Q$ 值の周波数特性においてコイル $\mathrm{A} の Q$ 值の最大值が $f=674 \mathrm{kHz}$ より低い周波数であった。コイル $\mathrm{A} の Q$ 值 の最大值を高周波に調整するためには, コイルの巻数 を減らす必要があったが巻数を減らすとコイルのイン ダクタが低下して全体の $Q$ 值が減少したため, 本実験 では，図中のような $Q$ 值の特性で実験を行った。

Fig. 9 に受電電力の周波数特性を示した。永久磁石 を受電コイルの近くに配置することにより受電電力が 低下して共振する周波数が上昇した。これは，永久磁 石の磁界が受電コイル内に鎖交することにより受電コ イルのインダクタンスが低下して共振周波数が増加し たためである。受電電力低下の原因として, 永久磁石 の磁界によるフェライトコアの磁気飽和と受電コイル のインダクタンス低下による $Q$ 值の減少が考えられる。

Fig.10に出力電力-角度特性を示した。伝送周波数は $694 \mathrm{kHz}$ とした。受電電力の周波数特性において受電 電力が少なかった $l_{\mathrm{PM}}=4 \mathrm{~mm}$ の永久磁石を配置した条 件で角度をパラメータとした受電電力を検討した。 $\varphi=$ $0^{\circ}, 15^{\circ}$ の場合において $\theta$ の角度が 0 ○から $45^{\circ}$ の受電電 力と比べ 90 叻ら 180 ○の間での受電電力が大きく受 電した。三軸コイルの作成にあたりコイル A とコイル B のコイルの巻き方に対称性が無く均一に磁界が鎖交 しないことやコアの形状の均一でないことが考えられ る。角度 $\theta=180^{\circ} \varphi=90^{\circ}$ のと最低受電電力 $186 \mathrm{~mW}$ であり ICNIRP のガイドラインを遵守した磁界におい て, カプセル内視鏡の駆動電力である $30 \mathrm{~mW}$ 以上 186 $\mathrm{mW}$ の電力を受電した[10]。

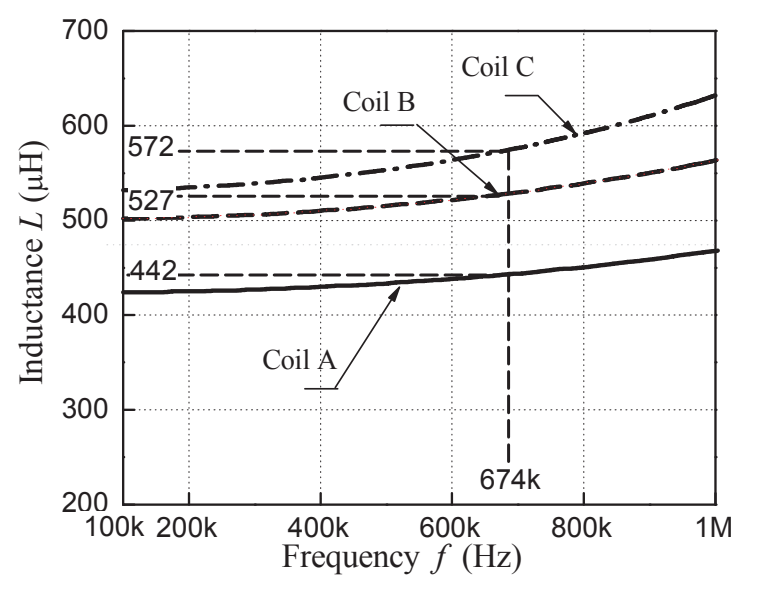

(a) Inductance

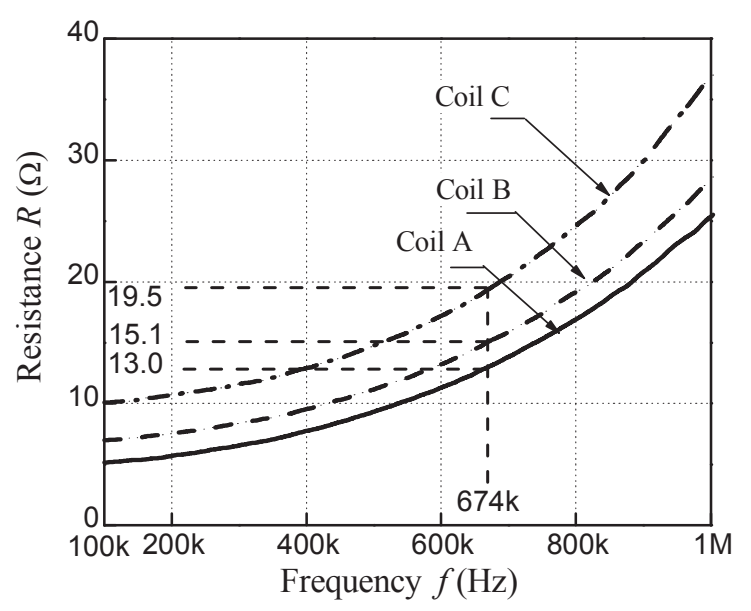

(b) Resistance

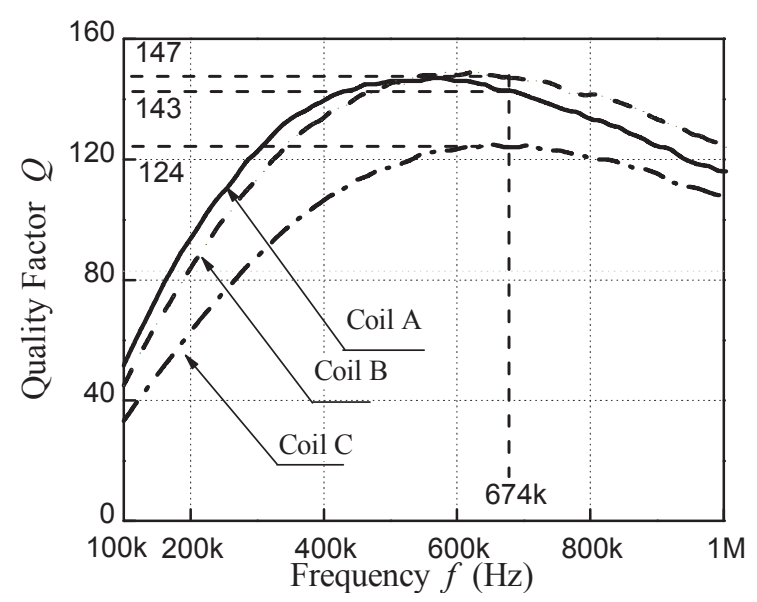

(c) Quality factor

Fig.8 Impedance vs. frequency characteristics. 
Fig.11 に出力電力-誘導磁界角度特性を示した。伝 送周波数は $694 \mathrm{kHz}$ とした。Fig.10 の結果で最も受電 電力が少なかった受電コイルの角度 $\theta=180^{\circ} \varphi=90^{\circ}$ において誘導磁界の角度をパラメータとして印加した 場合の受電電力を検討した。誘導磁界は誘導に必要な 磁界より大きい $10 \mathrm{mT}$ とした。 $\alpha=0^{\circ} \beta=30^{\circ}$ のとき最 低受電電力 $168 \mathrm{~mW}$ であり誘導磁界に印加した場合に おいてもカプセル内視鏡の駆動電力である $30 \mathrm{~mW}$ 以 上 $168 \mathrm{~mW}$ の電力を受電した。

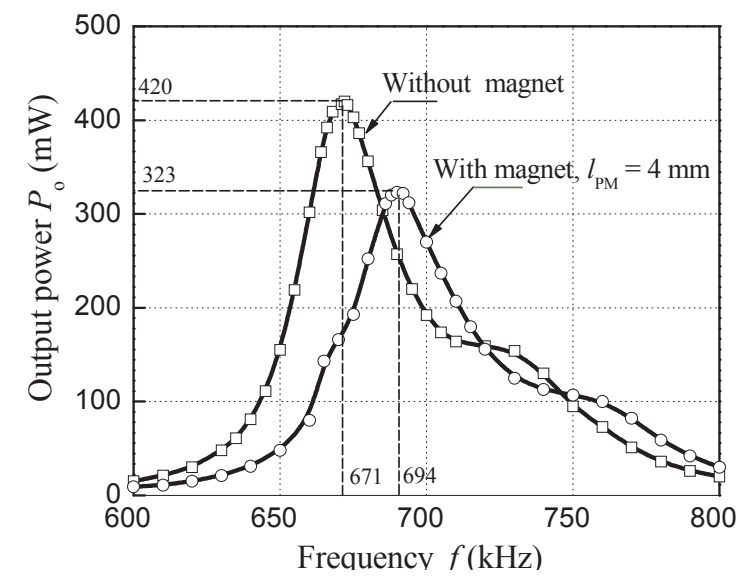

Fig. 9 Output power vs. frequency characteristics.

\section{4 カプセルの推進力特性}

Fig. 12 に推進力測定ブロック図を示した。NF 回路 設計ブロック社製発振器(WF 1974)からの信号をNF 回 路設計ブロック社製パワーアンプ(BP 4610) を用いて 増幅し, コイルに $1 \mathrm{~A} \sim 5 \mathrm{~A}$ の直流電流を流して, 勾配 した磁界を発生させた。勾配した磁界とカプセル内の 永久磁石との推進力をカプセルとばねばかりをビニル ひもで繋げて計測した。

Fig.13 に推進用コイルの磁束密度分布を示した。本 実験では, $l=20 \mathrm{~mm}$ の位置にカプセルを配置し, $1 \mathrm{~A} \sim$ 5 A まで直流電流をコイルに流してコイルの発生した 磁気勾配による永久磁石との磁気吸引力をカプセルの 推進力として実験を行った

Fig.14 に電流-推進力特性を示した。推進用コイルに $5 \mathrm{~A}$ の電流を流したとき, 永久磁石だけのカプセルと比 較して受電コイルを含むカプセルの推進力が $17.5 \%$ 増 加し $94 \mathrm{mN}$ であった。受電コイルを装着することで推 進力が増加した。受電コイルのフェライトコアや磁性 めっき線の鉄薄膜が永久磁石により磁化され磁石とみ なせる容量が増加し推進力も増加したと考えられる。

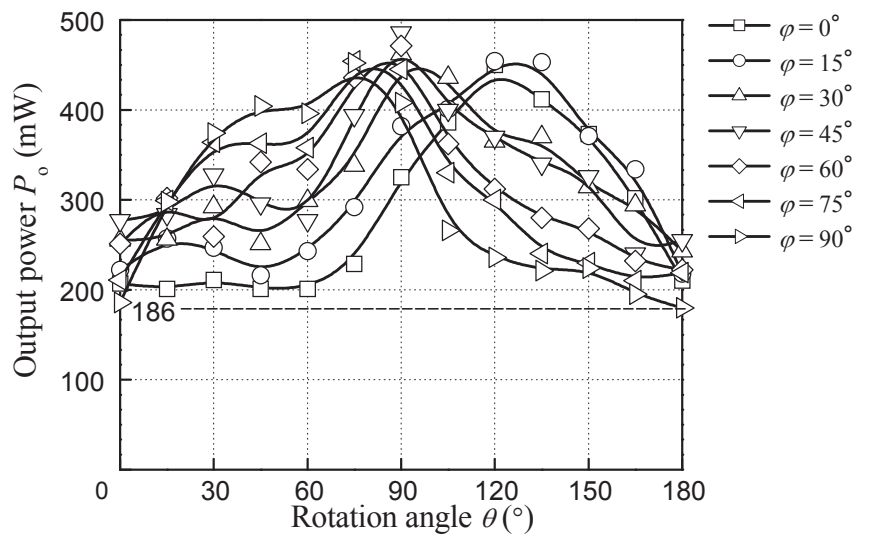

Fig. 10 Output power vs. angle characteristics. $\left(H=80 \mathrm{~A} / \mathrm{m}, f=694 \mathrm{kHz}, l_{\mathrm{PM}}=4 \mathrm{~mm}\right)$.

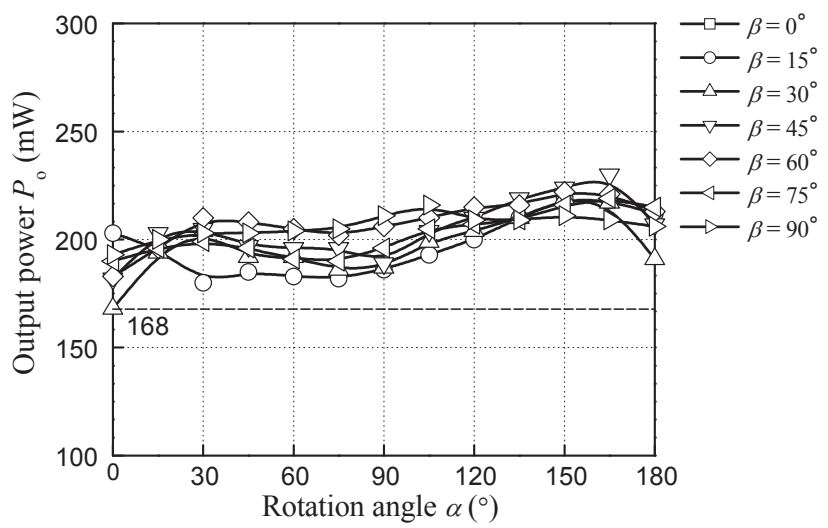

Fig. 11 Output power vs. self-propelled magnetic field angle characteristics.

$\left(H=80 \mathrm{~A} / \mathrm{m}, f=694 \mathrm{kHz}, l_{\mathrm{PM}}=4 \mathrm{~mm}, B=10 \mathrm{mT}, \theta=180^{\circ} \varphi=90^{\circ}\right)$.

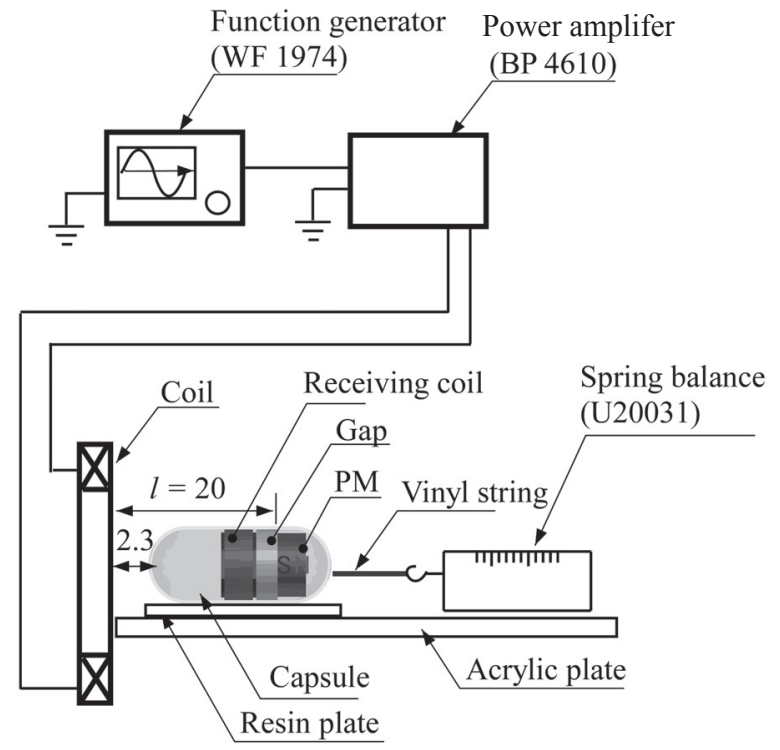

Fig. 12 Driving force measurement block diagram (unit : mm). 


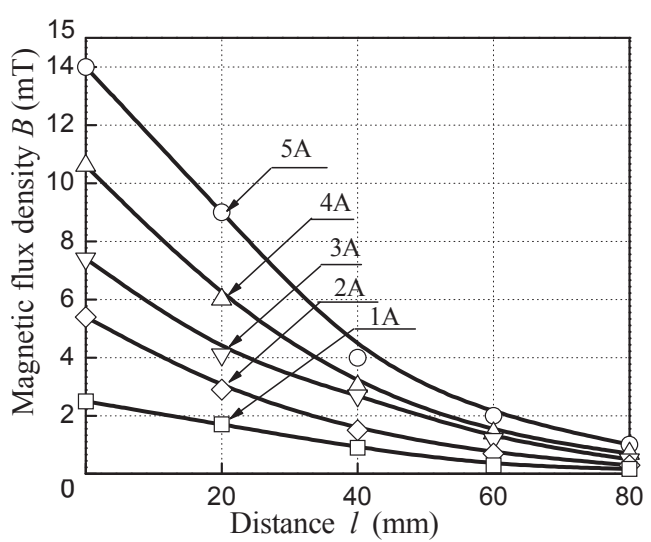

Fig. 13 Magnetic flux density distribution of the coil.

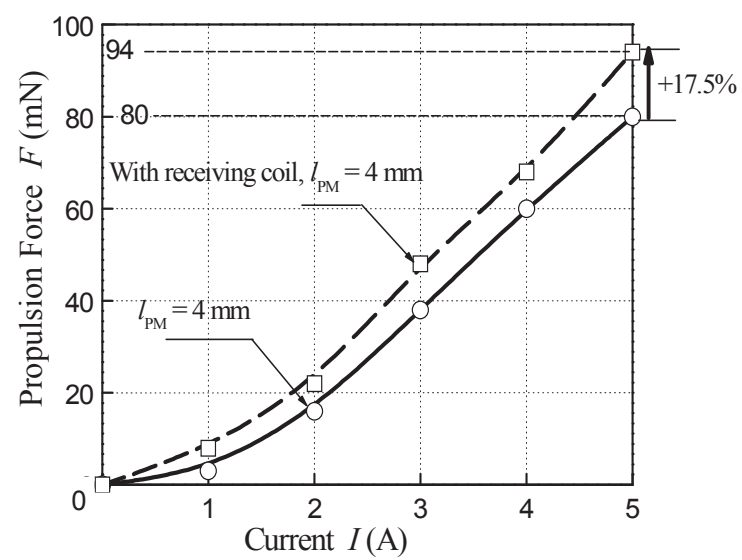

Fig. 14 Current vs. propulsion force characteristics of the capsule.

\section{5 あとがき}

本論文で述べたことをまとめると以下のようにな る。

\section{(1) 受電電力特性}

受電電力の周波数特性において永久磁石を近くに 配置すると受電電力が低下して共振する周波数が増加 した。永久磁石の磁界が受電コイルに鎖交することに よりインダクタンスが低下して共振周波数が増加した と考えられる。受電電力低下の原因として, 永久磁石 の磁界によるフェライトコアの磁気飽和とインダクタ ンス低下による $Q$ 值の減少が考えられる。

角度をパラメータとした受電電力において $l_{\mathrm{PM}}=4$ $\mathrm{mm}$ の永久磁石を受電コイルに付属した場合で角度 $\theta$ $=180^{\circ} \varphi=90^{\circ}$ のさ最低受電電力 $186 \mathrm{~mW}$ であった。 また, 誘導磁界を印加した場合において角度 $\alpha=0^{\circ} \beta=$ $30 \circ$ とき最低受電電力 $168 \mathrm{~mW}$ であり ICNIRPのガイ ドラインを遵守した磁界において，カプセル内視鏡の
駆動電力である $30 \mathrm{~mW}$ 以上を受電できた。

(2) 推進力特性

推進用コイルに $5 \mathrm{~A}$ の電流を流したとき, 永久磁石 だけのカプセルと比較して受電コイルを含むカプセル の推進力が $l_{\mathrm{PM}}=4 \mathrm{~mm}$ のとき $17.5 \%$ 増加し $94 \mathrm{mN}$ であ った。受電コイルを装着することで推進力が増加した。

\section{謝辞}

本研究では科学技術振興機構(A-STEP 探索, 課題番 号：AS262Z00433P)の助成を受けたものであり，謝意 を表する。

\section{参考文献}

[1] IKEDA. Keiichi, SWAIN C.Paul, TAJIRI Hisao, The Cutting Edge of Capsule Endoscopy Development and Innovations-Past, Present, and Future, Capsule Endoscopy, Vol. 17, pp. 481-491, 2005.

[2] 小西聡, 診断・治療のためのマイクロ体内ロボット, ロボ ット, No. 178, pp. 7-12, 2007.

[3] 田尻 久雄, 大腸カプセル内視鏡検査の現状と課題, 日本 消化器内視鏡学会雑誌，Vol. 53(9), pp. 2988-2999, 2011.

[4] 和多田 雅哉, 小澤 健一, カプセル型内視鏡への搭載を 目的とした自走機構の開発，日本 AEM 学会誌，Vol. 18, No. 3, pp. 251-256, 2010.

[5] R. Puers, R. Carta and J. Thone : Wireless power and data transmission strategies for next-generation capsule endoscopes, J Micromech. Microeng, Vol. 21, No. 5, 1-15, pp. 054008, 2011.

[6] ICNIRP, On the guidelines for limiting exposure to time-varying electric and magnetic fields $(1 \mathrm{~Hz}-100 \mathrm{kHz})$ published in health phys. 99(6), pp. 818-836, 2010.

[7] 中園聡，池畑政輝，山崎健一，多氣昌生，伊良皆啓治，重 光司，医療技術における磁気応用研究の動向(6) - 医療機 器における磁界利用のガイドライン-, 電気学会マグネテ イックス研究会資料, Vol. MAG-12-17, LD-12-17, No. 12-22, pp. 31-36, 2012.

[8] Kunihisa Tashiro, Genya Hattori, Hiroyuki Wakiwaka, Magnetic flux concentrarion methods for magnetic energy harvesting module, EPJ Web Conferences, 40, 06011, 2013.

[9] 水間淳一郎, 後藤徳仁, 卜穎剛, 水野勉, 体内ロボット用 非接触給電における周波数と給電領域の検討, 日本 AEM 学会誌, Vol. 23, No. 1, pp. 144-150, 2015.

[10] 中島武信, 和多田雅哉, カプセル内視鏡への非接触給電 を目的とした電力伝送の検討, 第 19 回 MAGDA コンフ アレンス論文集, pp. 509-512, 2010. 